Aletria, Belo Horizonte, v. 30, n. 1, p. 45-63, 2020

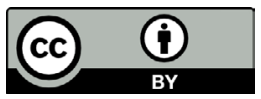

\title{
Fazendo arte para ativar o pensamento crítico ${ }^{1}$
}

\section{Creating Art to Activate Critical Thinking}

\author{
Marília Rothier Cardoso \\ Pontifícia Universidade do Rio de Janeiro (PUC-Rio), Rio de Janeiro, Rio de Janeiro / \\ Brasil \\ mariliarothier@gmail.com \\ https://orcid.org/0000-0001-9509-1512
}

Resumo: Um trajeto livre pela diversidade de publicações de Silviano Santiago surpreende o observador, pois mostra como a potência da fabulação literária amplia o teor inventivo da atividade teórico-crítico-política. Partindo de um texto circunstancialo conto "Família", publicado no blog do Instituto Moreira Salles por ocasião da abertura da exposição de fotografias de Chichico Alkmim -, este artigo visita obras de gêneros, estilos e tons muito diferentes na investigação de momentos de destaque onde a escrita, ao experimentar soluções mais instigantes, ilumina problemas de formulação conceitual e de julgamento crítico. Ora deixa evidente a permanência da força denunciadora das apropriações e montagens, ora exercita a narração do ponto de vista da criança para estranhar comportamentos sociais arraigados; numa passagem poética, ressignificam-se personagens da mídia de massa; nas narrações, serve-se da tática (auto)biográfica para reescrever aspectos delicados da história recente; por último, seus enredos romanescos transformam o estatuto mimético do gênero em alegoria de aspectos teóricos da arte.

Palavras-chave: ficção artística; exercício crítico; montagens verbais e plásticas; autoficção.

Abstract: A free path through the diversity of publications by Silviano Santiago surprises the reader, as it shows how the power of literary fabulation expands the inventive content of theoretical-critical-political activity. Starting from a circumstantial

\footnotetext{
${ }^{1}$ Agradeço a parceria com Aline Leal Barbosa na pesquisa para este artigo.
} 
text - the short story "Família", published on Moreira Salles Institute blog for the occasion of Chichico Alkmim's photography exhibition opening -, this article visits writings distinct genres, styles and tones in the investigation of outstanding moments where writing, by experimenting with more thought-provoking solutions, illuminates problems of conceptual formulation and critical judgment. Sometimes it makes clear the permanence of the denouncing force of appropriations and assemblages, at other times it exercises the narration from a child's point of view to alienate entrenched social behaviors; in a poetic extract, it re-signifies mass media characters; in narration, the (auto) biographical tactic is used to rewrite polemic aspects of recent history; lastly, the novelistic plots transform the mimetic status of the genre into allegory of theoretical aspects of art.

Keywords: artistic fiction; critical exercise; verbal and plastic montages; self-fiction.

\section{A propósito de uma foto}

A escrita de Silviano Santiago põe em alerta o leitor mais indiferente ou distraído. O rigor analítico-avaliativo de seus ensaios intensifica-se pela economia tensa das articulações artísticas que os constroem. As sensações produzidas por suas cenas narrativas, ao longo do encadeamento visual e rítmico, condensam a agudeza do raciocínio crítico. $\mathrm{O}$ conjunto de seus trabalhos o situa, em potência plena, como poeta-crítico. A acuidade das percepções, que ele transmite ao público, evidente nos empreendimentos de fôlego - para os quais deve ter-se preparado em longas pesquisas -, mantém-se, com a mesma força, nas encomendas urgentes, desempenhadas no tempo escasso do jornalismo. É instigante observar a maestria do artista, que domina seu ofício, considerando a resolução perfeita de uma peça de circunstância. Assim se apresenta "Família", narrativa curta publicada em maio no blog do Instituto Moreira Salles (IMS) por ocasião da mostra do fotógrafo mineiro Chichico Alkmim. ${ }^{2}$

As artes plásticas sempre instigaram a imaginação ficcional e teórico-crítica de Silviano. E, várias vezes, como no caso deste conto, foi a memória infantil, recuperada na maturidade, que guiou o traçado escritural, na tarefa de desvendar, em suas tensões complexas, a banalidade aparente do cotidiano. Em Uma história de família, romance

${ }^{2}$ A maneira como o conto "Família" usa, em duas versões, a fotografia de Chichico Alkmim pode ser vista em Santiago (2017). https:/ims.com.br/por-dentro-acervos/familia/ 
de 1992 - com epígrafe e capa reproduzindo frase e assemblage de Arthur Bispo do Rosário -, o narrador se vale de sua recordação de menino para expor uma cena chocante, difícil de decifrar. A criança, tomando café com leite, no refeitório da pensão da avó, ouvia frases estranhamente violentas, ditas por esta, diante de Mário, seu tio, dado por louco e transformado em assunto tabu entre os parentes. Para desvendar essa lembrança incômoda, a voz perplexa que narra, primeiro, descreve a fisionomia enigmática do tio Mário, como se a visse numa "fotografia 3X4" (SANTIAGO, 1992, p. 19). Em seguida, tomando a foto por um fotograma, contrasta-a aos fotogramas anterior - "o rosto conselheiro" da comadre Marta - e posterior - a fisionomia violenta de sua avó, mãe inconformada daquele homem incontrolável que todos rejeitavam. Da referência à fotografia, o texto passa à do cinema. É a teoria eisensteiniana da montagem que socorre o narrador na decifração da lembrança amarga. $\mathrm{O}$ recorte e a colagem, explorados pelos artistas modernos, somaramse a novos conhecimentos, como a psicanálise e a filosofia política de Nietzsche, para instrumentalizar artistas e críticos em suas investigações da experiência social. Mas essas técnicas de leitura dos cenários e comportamentos mostraram-se - e mostram-se - efetivas justamente porque foram compostas no intervalo entre os conceitos e os perceptos, a inteligência filosófico-científica e a sensibilidade aguda da arte.

Por certo, Silviano encontrou, na precisão elegante das fotografias do conterrâneo Chichico, uma parceria discreta no propósito de estudar, pelo jogo de sombreamento e iluminação, as tensões, tão poderosas quanto dissimuladas, do sistema patriarcal, resistente mesmo nas cidades e nas décadas de maior progresso. Tendo-se profissionalizado como retratista, o fotógrafo diamantinense manejava, com os recursos da época (primeira metade do século XX), uma linguagem capaz de inserir, no documento visual, acréscimos sutis, resultantes dos cenários, figurinos e objetos, que reinventavam seus modelos, de modo a insinuar sua efetiva posição na comédia familiar e comunitária, que, ali, se desenrolava. É a dimensão ficcional do retrato que o torna uma arte. Tanto os fotógrafos quanto os romancistas sabem muito bem disso, em especial e contraditoriamente, quando se dedicam a empreitadas autobiográficas.

Convidado para escrever uma ficção sobre a fotografia de Chichico Alkmim, o escritor apropriou-se, como artista da palavra, desta imagem que se destaca pela aparência desconcertante e, por isso, poderosa. Impossível deixar de fixar várias vezes o conjunto convencional da 
família burguesa - bem-posta em sua elegância - falseado pela evidência de que posa sobre fundo cenográfico e deve seu lugar de distinção ao suporte dos criados. Diante dessa fotografia incomum, o autor de $O$ falso mentiroso (2004) não se limitaria a narrar o episódio que reuniu o casal, seus filhos pequenos e as criadas. Instigado pela dimensão metalinguística da imagem, aproveitou o jogo de equívocos, proposto por esse trabalho de estúdio, deslocado para o ar livre de um quintal em obras. Na presença inesperada do making of de um processo fotográfico, Silviano Santiago construiu uma invenção memorialística que supõe destruição, recorte e recomposição da clássica figura familiar, revelando a desarmonia mal disfarçada pelo decoro imposto pela remanescente autoridade patriarcal. Ao transformar os elementos do retrato em enredo narrativo, desvenda as tensões que, ao mesmo tempo, unem e separam as personagens em cena.

Conhecendo a obra do fotógrafo e sabendo da inserção de um referente autobiográfico na mesma, o ficcionista retoma a estratégia usada em três de seus romances e escolhe, como ponto de vista narrativo, o menino que parece indisposto com a ordem de posar para a objetiva. É o olhar desarmado da criança que o adulto recupera, décadas depois, na tarefa crítica de expor conflitos abafados, com o claro propósito de empregar o expediente estético na encenação de contrastes.

A rememoração literária da cena diamantinense, gravada em vidro e reproduzida em papel, situa-se, no entanto, na Belo Horizonte dos anos cinquenta. Homem feito, a personagem-narrador encontra o retrato nos guardados da mãe, já morta. Numa espécie de variação das rasuras de um retrato tirado como que à revelia do desejo de seus modelos, o conto menciona, de início, a curiosidade do homem que encontra, esquecida na gaveta, uma fotografia rasgada e recomposta com cola sobre cartolina. Reavivada a lembrança do momento pretérito, o narrador sai em busca do episódio que teria desencadeado tantos gestos descabidos e raivosos. $\mathrm{Na}$ urdidura do conto despretensioso, patenteia-se a mesma argúcia que criou os enredos complexos de Uma história de família e d'O falso mentiroso. Aí é que o artesanato linguístico passa a desvendar as marcas onde a imagem cifrou, em sua economia necessária, os diferentes tempos da convivência familiar, superpostos na simultaneidade das figuras retratadas e premonitores do desenlace futuro.

A licença poética do anacronismo, que obriga o narrador da história curta a explicar as polainas usadas pela figura paterna, permite que o artesão da palavra condense a análise do papel do retratista- 
expert, atuando em uma Diamantina ainda apegada aos costumes europeus da belle-époque, à crítica da sociedade metropolitana, presa ao conservadorismo confortável à elite, que se modernizou sem abrir mão do comportamento autoritário. Quando o narrador do conto, considerando sua fisionomia de menino "embirrado" (SANTIAGO, 2017), ${ }^{3}$ nega que sua mão esquerda estivesse batendo continência e afirma que coçava a cabeça, aponta, indiretamente, no contraste entre empregados e patrões, o desequilíbrio cruel que a grande maioria das fotos de Chichico Alkmim procura harmonizar. Mestre das palavras que produzem o efeito de imagens vivas, Silviano capta a perfeição técnica das imagens de Chichico e aproveita a precisão das mesmas para apontar, no seu contraste de luz e sombra, as artimanhas do profissional liberal/chefe de família para manter sua posição em casa e na sociedade. Atente-se para o poema "Pai" de Crescendo durante a guerra numa província ultramarina:

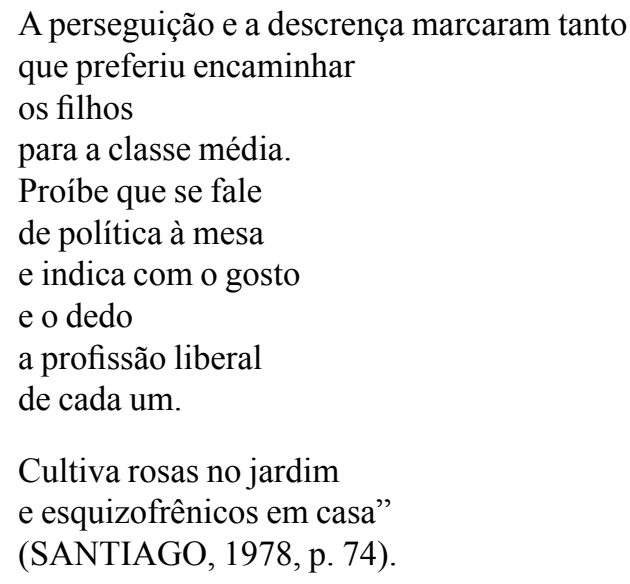

A composição dupla dessa inusitada fotografia de família ressalta o contraponto crítico - evidente, seja pelo desejo de experimentação estética, seja pela intenção de interferência na ordem social -, na urdidura da ficção narrativa, que alterna a perplexidade infantil e as inquirições do adulto. Sendo assim, não resta dúvida de que arte e análise avaliadora de atitudes e comportamentos formam as faces da mesma moeda. Reforçando o que foi dito de início: em seu estatuto de prosa circunstancial, "Família"

\footnotetext{
${ }^{3}$ Extraído do Blog do Instituto Moreira Salles. As demais referências ao texto de Silviano publicado no blog do IMS provêm do mesmo endereço de acesso.
} 
é uma ficção ensaística. Transpõe o instante fotográfico para a sequência narrativa não só para exercitar, verbalmente, o pastiche de uma imagem, mas, antes de mais nada, para levar mais longe a insinuação crítica de seu antecessor. Enquanto a foto de Chichico sugere o conflito surdo entre as classes sociais e entre as gerações de uma família, Silviano inventa um narrador velho e menino, que se detém diante de fraturas e reparos, impelido pela vontade de dar voz ao que foi silenciado. Longe do sarcasmo do narrador protagonista de $O$ falso mentiroso, diferente da curiosidade necessária e cruel do sobrinho já doente, que se equipara ao rejeitado Tio Mário, em Uma história de família, a voz que recompõe a trajetória de uma foto doméstica faz-se inquisidora e sóbria, mas decidida a quebrar tabus. O sobrinho do tio Mário procura o médico de seus parentes na expectativa de desmascarar a boa sociedade interiorana, dando crédito, finalmente, ao sorriso constante do louco, de que todos os bem pensantes queriam livrar-se. Por sua vez, anos depois, o menino que perturbou a pose da família, olhando de soslaio e coçando a cabeça, vai em busca do fotógrafo querendo conhecer os termos da negociação entre seu pai e o profissional dos retratos. Constrói, de propósito, no lugar da discrição elegante de Chichico, um fotógrafo malicioso e desabrido, que reafirma sua intenção de que a fotografia revelasse a usura arrogante daquele pai de família aparentemente exemplar.

Para que o público visitasse a exposição do acervo fotográfico de Chichico Alkmim, com olhos bem abertos, sem deixar-se seduzir e enganar pelo bom gosto do retratista, nada mais próprio do que o convite a Silviano Santiago para um comentário através da ficção. Sempre um pensador da arte, apto a rever noções e aprimorar critérios, o poeta-crítico mantém-se atento às criações de seus contemporâneos e antecessores. Nesse empenho tenaz de leitura e escrita, acaba de inventar a figura do velho Machado de Assis, transitando pela belle époque carioca e desmentindo, com a correção cruel de seus últimos romances, o equilíbrio aspirado pela arquitetura daquele período que se queria progressista. Os interiores suntuosos e a prosa ornamental - orgulho da nova elite - foram confrontados pelos capítulos breves de Esaú e Jacó e pela despretensão proposital com que o Conselheiro Aires registrava seu diário. Ambos exibiam a fragilidade da abolição incompleta e da república proclamada em atropelo. A escrita de Silviano trata esse confronto como se observasse um postal art nouveau da Avenida Central rasgado e recomposto, na expectativa frágil de reforçar os alicerces da nação. 
O melhor modo de conhecer a trama delicada do artesanato escritural do romancista experiente foi a evocação das frases dos interlocutores, que ele destacou no final da carreira. Obcecado pela "transfiguração" - resgate da dor em beleza -, o Machado de Silviano revisita a tela de Rafael através da leitura de Stendhal e da lembrança de Joaquim Nabuco. Instado a fazer uma foto fora do estúdio, o Chichico de Silviano teria pedido a sua própria mulher e, possivelmente, a uma "cria da casa" para segurar o painel que enquadrasse a família devidamente paramentada. E se, no último Machado, o crítico pode ler menos o milagre que a força da vontade perscrutadora do real, no trabalho do fotógrafo mineiro encontrou o desgaste do modelo familiar e a crueza das relações em sociedade. Assim, o conto "Família" serve de réplica, em miniatura, ao romance Machado, onde também se poderia vislumbrar, pelas brechas das reformas improvisadas e pelas beiradas dos painéis exíguos, a multidão dos trabalhadores desalojados. Tanto no esforço máximo de reinventar a arte do escritor, relendo-lhe a correspondência, como na quase brincadeira de simular a mágica do fotógrafo, perscrutando-lhe o trabalho, a produção do mesmo "impacto dos paradoxos estéticos" (SANTIAGO, 2016, p. 383). Lá como cá, "[a]lgo do acabado só se conhece pelo inacabado" (SANTIAGO, 2017).

\section{Ponto de vista infantil}

Toda a obra de Silviano Santiago constrói-se a partir da consciência de que a arte só alcança potência plena quando se vale de sua dimensão ficcional para exercitar o pensamento especulativo e autocrítico. Dedicando-se com o mesmo empenho ao ensaio teóricoanalítico e à literatura, exercita sua inventividade em paralelo com práticas investigativas para que o processo criativo se faça acompanhar de constante autoavaliação. Em seus contos e romances, frequentemente exibem-se fragmentos do making of, num jogo tenso entre o prazer do lance ilusionista e o trabalho rigoroso da análise e discussão. Quando visitou a coleção de Chichico Alkmim, deve ter-se fixado, imediatamente, nesta foto autorreferente e incômoda onde a grande abertura do foco obriga o espectador a comparar a pose elegante das figuras a serem retratadas (contra o painel artificial) ao desleixo dos fundos da residência e a posição constrangida da mulher e da criança, obrigadas ao trabalho extraordinário de sustentar o fundo falso da imagem formalizada. 
O procedimento inesperado do fotógrafo profissional precede e como que autoriza a petulância com que o romancista insere, em seus enredos, cenas onde a operação escritural é que ocupa o centro do capítulo. A atenção do narrador converge para ela e é o impacto das frases manuscritas ou digitadas que se confronta seja com o entorno do espaço ficcional seja com o recorte histórico-social que vai se compondo ao registrar-se no papel ou na tela do computador.

Heranças, romance de 2008, apresenta-se na forma autobiográfica e, já no primeiro capítulo, traz o protagonista narrador, um velho solitário, recentemente transferido de Belo Horizonte para um amplo apartamento carioca da Vieira Souto, digitando suas memórias. Surge o incômodo quando, como ele anota, "[a] copeira bate à porta do escritório e interrompe bruscamente o diálogo que mantenho comigo na tela do computador" (SANTIAGO, 2008, p. 12). A distância entre patrão e empregada, causadora de certo desconforto, desencadeia a série de tensões, avivadas pela escrita. No presente, a tranquilidade do milionário, que pode se dar ao luxo da mudança para o novo endereço e do planejamento cuidadoso de seu enterro; no passado - reconstituído pelo texto em construção, como última aventura arriscada -, a denúncia da violência camuflada das ações que garantiram que ele, o memorialista, recebesse a totalidade dos bens da família. Distante da graça sutil do conto que comenta a fotografia do Alkmim, as memórias desse herdeiro produzem efeito de humor negro "num texto escrito em hieróglifos" (SANTIAGO, 2008, p. 16). Comparando-se a ninguém menos que Champollion (o responsável pela tradução da escrita egípcia), o narrador orgulha-se da obsessão com que descreve os atos escusos dos quais, no torvelinho dos negócios, nem chegou a dar-se conta. Para ele: "[p]ela correspondência entre os dados decifrados de episódio vivido e as criptografias dum outro, [...] é que irei destrinchar minha experiência de vida [...]" (SANTIAGO, 2008, p. 16).

Enquanto a convenção referente à fotografia artística do século XIX recomendava o disfarce de seus truques como garantia da verossimilhança, cara à ascensão no mercado, a arte posterior às vanguardas, com a ruptura definitiva da racionalidade realista, impõe estratégias diversas de metalinguagem com o objetivo tanto de jogar, de modo esclarecedor, com o ilusionismo, quanto de expor o trabalho necessário ao apelo estético. Tal experimento laborioso proposital deve, em paralelo, operar, até o limite do possível, a denúncia dos controles e exigências político-sociais. Com seu estatuto ficcional, a arte abre brechas 
nas normas estabelecidas e, assim, vê-se na responsabilidade de cumprir essa tarefa de resistência.

Se o narrador de Heranças não se apresenta como artista e, por isso, seu desejo investigativo concentra-se nas trapaças da economia burguesa que, de tão comuns, tornaram-se invisíveis, já a composição de Stella Manhattan (1985) busca, explicitamente, articular as dimensões política, filosófica e artística, no enfoque de fatia próxima do passado os anos da ditadura militar no Brasil, marcados por repressão e censura. Aí, os experimentos metalinguísticos combinam-se com a apropriação de complexas soluções do campo das artes plásticas. Em alerta ao leitor, grava-se, ao final do texto, esta nota: "Narrador e personagens dobradiças, homenagem aos 'Bichos', de Lygia Clark, e a 'La Poupée', de Hans Bellmer" (SANTIAGO, 1985). Entre os capítulos, redigidos em terceira pessoa, que dão conta da trama de brasileiros vivendo em Nova Iorque para escapar ou resistir à ditadura, inserem-se aqueles onde o narrador duplicado - realiza e discute o ato de escrever. O texto desses capítulos grafa-se todo entre parênteses, indicando a diferença de plano, em que se situa, frente à ação romanesca. Trata-se do propósito de expor a escrita artística em ato:

(Estou de pé, por detrás da cadeira em que você está sentado escrevendo, e leio no bloco - por sobre os seus ombros - essas anotações [...] que você está jogando no papel em dezembro de 1982, época em que você acredita que já está pronto para um novo romance. [...]

Você se vira para mim e me diz que me despreza agora. [...] Você continua me chamando de seu primeiro leitor de merda. [...] que não te ajudo em nada; pelo contrário, só sirvo pata te inibir [...]

Vira-se para mim e diz que na verdade sou eu quem tem razão e que você realmente não gosta de narrativas autobiográficas. [...]) (SANTIAGO, 1985, p. 72, 74).

O caráter necessária e laboriosamente construído da literatura se materializa, diante do leitor do romance, por meio dessa operação perspicaz de incorporar virtualmente as duas faces do literato - aquela que conduz a operação inventivo-formatadora e aquela que a problematiza visando o constante aperfeiçoamento. A elaboração de um romance que superpõe assuntos polêmicos, como a política repressora e a não menos repressora moral social, em paralelo com o pensamento conservador, 
tem sua dimensão complexa e sua condição insegura evidenciadas pelo registro alternado de vozes em diálogo.

([...] Pelo silêncio, vou te dizendo que o importante [...] é que continue a te dar corda para que você vá soltando pelo papel coisas que iam morrer caladas no túmulo com você. [...]

Você continua a rir de mim e eu pensando como são falsos os romances que só transmitem a continuidade da ação, mas nunca transmitem a descontinuidade da criação. [...])" (SANTIAGO, 1985, p. 85, 86).

Nesses capítulos colocados entre parênteses, vislumbra-se o movimento das "dobradiças": oscilações do narrador (ora corajoso no rompimento de convenções e tabus, ora duvidoso quanto ao resultado artístico-crítico de suas ousadias confessionais e liberdades tomadas com a gramática), transfigurações das personagens (oscilantes entre a obediência social garantidora de conforto e sucesso e a expectativa do prazer no comportamento liberado), bem como mudanças de atitude mantidas pela sobrevivência em contextos de violência. As altas exigências próprias da arte que pretende expor oscilações e mudanças inesperadas são respondidas por um corpo escritural feito de materiais tão heterogêneos e flexíveis quanto as obras de Clark e Bellmer; tons, estilos e registros de linguagem se alternam e contaminam na construção inventiva e dispendiosa de cada capítulo.

\section{Arte como encenação}

Mesmo num texto de circunstância, despretensioso, como o conto "Família", encomendado por ocasião da mostra de fotografias de Chichico Alkmim, fica evidente a experiência de Silviano Santigo no tratamento com as imagens. Professor de literatura e artista da palavra, ele se aproxima, com competência e gosto, do cinema e das artes plásticas. Como crítico, transita, desenvolto, entre os dois espaços. Em qualquer deles, também se serve de fundamentos sólidos na teoria das linguagens e nas chamadas ciências sociais. Quando se busca, como aqui, rastrear o exercício da crítica histórico-política desenvolvida através da arte, cabe observar um dos ensaios de crítica a obras plásticas. A atenção voltada para a invenção artística, no momento mesmo de sua concretização 
material, sugere a leitura do ensaio sobre trabalhos de Adriana Varejão, que recebeu o título de "Para uma poética da encenação".

Ao observar como a artista se apropria de diferentes imagens europeias dos séculos XVI, XVII e XVIII - azulejos, desenhos e mapas - para contrapor-se à história dos conquistadores, gravando sua leitura dos acontecimentos pela perspectiva americanista, Santiago opera com o conceito de "encenação". O mesmo conceito que permite o enfoque anticonvencional das tarefas do fotógrafo e do romancista - tarefas desempenhadas na contramão das expectativas convencionais e das injunções políticas. Seu interesse pelo trabalho de Adriana Varejão certamente resulta da prática do "usocapião" (SANTIAGO, 2019, p. 140), por parte dessa artista, que cria subvertendo o desenho alheio: superpõe "a imagem pré-cabralina de uma protagonista feminina e selvagem" (SANTIAGO, 2019, p. 133) à figura masculina característica do panorama presente na azulejaria portuguesa. Assim, subverte o olhar hegemônico pelo prisma marginal, invadindo a própria cena da tradição pictórica. Faz ressaltarem as formas eloquentes, em articulação não discursiva, para romper também com a linearidade da história.

Quando trata das "imagens encenadas por Adriana” (SANTIAGO, 2019, p. 140), o crítico retoma a noção de duplicidade - agora em relação ao momento da leitura -, considerando que, diante da montagem e outras interferências sobre as imagens apropriadas, o observador opera simultaneamente como recriador/decifrador da obra:

[...] o leitor outro - aquele que fica por detrás dos ombros da artista, o mais visionário dos visionários, também chamado de crítico - nelas descobre significados impensados por Adriana, mas entrevistos por ele em imagens que the são particulares. (SANTIAGO, 2019, p. 140).

Todas as considerações sobre a reinvenção, através do "usocapião" de fragmentos dos arquivos da arte, sempre deslocando o olhar entre o objeto artístico e os materiais escolhidos para construí-lo, confirmam o estatuto complexo das escritas verbais e visuais. Trata-se de escritas onde a autoencenação do trabalho construtor engendra uma nova leitura do mundo. 


\section{Rememoração em montagem de fragmentos}

Ainda que se atravesse, rapidamente, o conjunto da obra, assinada por Silviano Santiago, não resta nenhuma dúvida de que a inventividade do ficcionista é que aguça o raciocínio teórico-crítico, seja apresentado em escrita ensaística, inserido na trama narrativa ou sugerido pelas imagens poéticas. Quando analisa e julga a arte alheia - verbal ou plástica -, sua observação perspicaz absorve a energia artística do objeto. Quando cria cenários e enredos ou quando encadeia séries imagético-sonoras, explora o dialogismo das encenações para esclarecer questões teóricas, no confronto de diferentes perspectivas. Esse rigor do gesto construtivo aproxima trabalhos muito distintos e de datas bem afastadas. O exercício do "usocapião", que surpreende nos painéis da artista, apropriadora da azulejaria e das cartas geográficas medievais e renascentistas, havia sido extensivamente praticado pelo crítico, décadas atrás, nos poemas de Crescendo durante a guerra numa província ultramarina (1978). Esse experimento poético singular bem pode corresponder ao imaginário daquele menino que coça a cabeça na foto de "Família". Trata-se de um registro de memória, totalmente vazio de confissões. Flashes de costumes interioranos, notícias, chavões retóricos, personagens dos quadrinhos e do cinema é que povoam a infância dos anos 1940. A atitude "cabisbaixa e embirrada" (SANTIAGO, 2017) do primogênito indicaria sua impaciência em trocar a autoridade paterna pela companhia excitante de seus heróis preferidos:

Ninguém sabe o que se passa

por detrás dessa máscara de Batman,

por detrás dessa fantasia de Super-Homem.

Só o Sombra sabe

(SANTIAGO, 1978, p. 16).

A mangueira é frondosa.

De galho em galho

salta Tarzã,

o rei dos macacos,

e encontra Silver à espera

[...]

e na nave espacial

agem Flash-Gordon,

de cabelos louros

e medievo, 


\author{
o Príncipe Valente \\ digladia em torneio \\ pelo amor de Jane \\ (SANTIAGO, 1978, p. 85).
}

Mas a temporalidade desses anos de construção de si mesmo, entre a opressão sub-reptícia dos próximos e a violência explícita da guerra distante, não é cronológica, muito menos evolutiva. O sujeito, em período de crescimento, não é mais que um ponto de vista - a perspectiva de onde se colecionam fragmentos dos discursos, circulantes nos anos 1940. É desse lugar de conhecimento em processo que se articulam os registros memorialísticos que povoarão a maturidade do crítico-artista. Estampamse lado a lado, confluentes e contrastantes, datados e recorrentes, a cautela do ditador esperto diante dos interesses externos - " [...] $]$ se não hostilizamos o capital estrangeiro, também não podemos conceder-lhes outros privilégios, além das garantias normais [...]" (SANTIAGO, 1978, p. 50) - e a estratégia do escritor de educar o povo, desde criança, pelo alter ego de uma boneca rebelde e espevitada: "Emília luta / contra Tarzã. / Lobato contra o entreguismo. / Uma questão de patriotismo" (SANTIAGO, 1978, p. 51).

Encadeados pelo ponto de vista infantil, os fragmentos discursivos (e algumas poucas imagens), que marcam a trajetória errática (ainda que historicamente definida) dessa espécie de arquivo de aprendizagem preservado no livro de 1978, nem delineiam o corpo de um protagonista, nem o situam em um ponto preciso da "província ultramarina". A versão poética é condensada, insistentemente lacunar; por isso, persegue o leitor como um fantasma, nunca passível de plena apreensão e domesticação. Já o menino, em Uma história de família, através de cujos olhos são expostas as ações escusas que compõem uma família de bem, apresenta-se cuidadosamente situado em cidades do interior mineiro, marcadas pelos costumes peculiares da gente local e imigrante assimilada. Caracterização cuidadosa de cenário e personagens são decisivos para o desenvolvimento paralelo da crítica à trama dos poderes no pequeno mundo doméstico. Ficou indicado, acima, como, a partir de uma virada insólita - uma fotografia rasgada e recomposta ou o descarte de um parente que escapa aos padrões considerados normais -, o narrador adulto persegue segredos violentos do período em que crescia sob as ordens familiares. Simultaneamente, o escritor experiente delineia, em traços ora rápidos, ora lentos e caprichosos, o esquema da narrativa contemporânea avessa 
ao ilusionismo realista. Decidida a exibir-se como rigoroso artifício do pensamento questionador. Especializando-se nesse tipo de arte metacrítica, Silviano Santiago explora as possibilidades territorializantes, mas paradoxalmente dessubjetivadoras do padrão autobiográfico.

\section{Biografia e autobiografia}

Como ficou registrado de início, a fotografia da família diamantinense de 1910 resulta de movimento inédito de Chichico Alkmim para preservar, na obra, seu processo de composição, deixando que se vislumbre seu conceito de fotografia. É retrato que sugere o desejo do artista de revelar o modo de construção de seu trabalho. Esse estatuto do fazer artístico, como articulação de imagens que incluem traços da fisionomia de quem o conduziu e assina, parece fundamentar a obra de Silviano Santiago. Em suas narrativas e coleções de poemas, as marcas identificadoras do autor se fazem visíveis - ou melhor, legíveis - na peça literária publicada sob a forma de margem metalinguística. A obra acabada, que põe à mostra elementos decisivos de sua construção, exibe simultaneamente resíduos autobiográficos do escritor - resíduos de vida e de experiência artística. Este se mostra um ponto de partida adequado para a leitura de Mil rosas roubadas (2014).

É o olhar infantil que a narrativa do adulto resgata, em Uma história de família (1992), para mostrar a rejeição de Tio Mário pelos parentes, vezeiros em comportamentos violentos mantidos em segredo. A maestria desse tipo de narração capaz de superpor perspectivas é que garante a importância do romance breve. Experimento semelhante conduz Heranças (2008), trajetória de ascensão econômica do protagonista conduzida ao sucesso por expedientes condenáveis, que se reconstitui pela narração de sua vida, quando, velho rico e solitário, dedica-se ao balanço do passado. Revelam-se as ações escusas pelo resgate e transferência, para a atividade de escrita, de seus desejos impacientes de menino e rapaz. As táticas, desenvolvidas nessas empreitadas dedicadas à busca de discutir e experimentar soluções novas para os impasses contemporâneos da literatura, conduziram Santiago à elaboração dos expedientes sofisticados com que explora as dimensões (auto)biográficas do romance, resgatando as incursões de jovens amigos no campo das artes, ambiente em que se destacam como adultos e que os torna observadores perspicazes da cena cultural e das carreiras de um e de outro. 
A superposição de pontos de vista - a perspectiva madura que se renova com os olhares infantil e adolescente - oferece base para a inescapável duplicidade da escrita (auto)biográfica. Mas, para a ambição investigativa da ficção de Silviano Santiago, isso não basta. Além do foco plural na condução do enredo, em sua complexidade, é necessário encontrar formas instigantes de expor, direta ou indiretamente, as táticas de cada etapa do desenvolvimento da escrita. O leitor deve encontrar pistas, no texto publicado, para captar as marcas cifradas tanto de lapsos involuntários quanto da autoconsciência criadora do artista.

O romance de 2014 realiza proposta ousada de discutir as imbricações entre ficção e (auto)biografia na constituição da escrita literária. Se, nos romances anteriores, a condensação dos pontos de vista narrativos dirigia-se, predominantemente, à denúncia do autoritarismo na convivência em sociedade, em Mil rosas roubadas é o circuito de aprendizagem, produção e circulação da arte que está sendo avaliado, através das táticas narrativas empregadas nas peripécias de seus protagonistas (o contraponto entre dois protagonistas resulta do constante deslizamento entre biografia e autobiografia ou, nos termos de outra camada significativa, entre as tarefas de investigação da vida do outro e o empenho da própria sensibilidade em registrar resultados de pesquisa em forma artística).

$\mathrm{O}$ argumento de Mil rosas roubadas pode resumir-se na transferência do lugar de biografado para o de biógrafo como expediente necessário à apreensão, por parte do pesquisador, da leveza intuitiva, rebelde, muitas vezes aparentemente aleatória do amigo, jornalista dedicado à música contemporânea. Com a lucidez do ensaísta, formado pela noção de que a arte se constitui num processo de dessubjetivação - o anonimato do artista é condição de dirigir-se ao público em termos coletivos -, Santiago vai trabalhando com uma cadeia de mediações para compor a biografia de Zeca (o adolescente precoce que se torna o grande divulgador da música internacional de ponta no Brasil). Observando o jogo escritural de que resultam os capítulos "Primeiro encontro" (SANTIAGO, 2014, p. 36) e "Borboletas-azuis" (SANTIAGO, 2014, p. 69), pode-se captar o modo de composição da série de intermediários evocada graças à engenhosa montagem da obra.

O narrador-biógrafo fornece data e circunstâncias de seu encontro com Zeca: 
Em fins de 1952, ele e eu caminhávamos ao léu no centro de Belo Horizonte e nos encontramos na praça de todos os encontros - a Sete de Setembro. [...] Dias antes tínhamonos entrevisto não na plateia do cinema Brasil, mas no Clube de Cinema. [...] Os dois eram exigentes em matéria de gosto artístico. (SANTIAGO, 2014, p. 61, 62).

Tendo-se reconhecido no acaso de estarem ambos na expectativa do mesmo bonde, Zeca toma a palavra e, loquaz, passa por diversos assuntos, desde seu gosto pela observação das pessoas, transitando pelas ruas da cidade, até uma coleção de borboletas, que se atribui. Aí se destacam as borboletas azuis, apresentadas através de longa exposição, que deixa o interlocutor perplexo. Depois de comentário provocador, o novo amigo se cala e o capítulo envereda por outro assunto.

Páginas adiante, abre-se outro capítulo onde o biógrafo dirige-se ao leitor para desculpar-se pela omissão de parte importante da conversa que marcou o primeiro encontro. Essa intromissão metalinguística, sob o título "Borboletas-azuis", funciona como, de um lado, a problematização da biografia histórica convencional, que apaga as marcas de sua construção para vender-se como verdade, e, de outro lado, a introdução da cadeia de encontros responsáveis pela formação intelectual e sensível do escritor. Assim, propositalmente, a biografia de Zeca inclui a de Vanessa, conhecedora das informações científicas sobre borboletas e leitora voraz, que introduziu Zeca no conhecimento das artes. A inclusão de Vanessa - como a de outras personagens e acontecimentos, ao longo do relato - ajuda o leitor do romance (auto)biográfico a duplicar sua atenção. Tal como a dissertação sobre borboletas surge como estranheza na fala de uma personagem urbana, a ordenação dos episódios narrativos também pode provocar incongruências. A escrita autocrítica serve-se dessas passagens desconexas para revelações decisivas: a importância da forma material da arte para a produção de seu sentido e a sobreposição de apropriações de enunciados alheios. São estes que constituem a urdidura de uma obra, testemunhando a formação plural e eclética de seu autor. Se o narrador-biógrafo, identificado como professor e pesquisador de história, estabelece aliança afetiva e intelectual com Zeca para tornar-se investigador inventivo, Zeca, por sua vez, incorporou saberes e afetos de outras amizades decisivas. $\mathrm{O}$ resultado da arte (auto)biográfica que lemos é a conjugação de inúmeras alianças, reconhecidas e esquecidas pelo autor que assina a obra: são "mil rosas roubadas". 


\section{Memória}

O primeiro número da revista Olympio de maio de 2018 publica, "em primeira mão", "Menino sem passado", fragmento inicial da obra memorialística em que Silviano Santiago trabalha no momento. Cuidadosamente situado na cidade de Formiga, Minas Gerais, onde nasceu, e nos anos 1940 da guerra na Europa e da ditadura Vargas no Brasil, reaparece o menino, já transfigurado em várias versões de ficção: o menino (ainda em trajes antiquados da fotografia de Chichico Alkmim) que posa como "presença cabisbaixa e embirrada" (SANTIAGO, 2017), o outro/mesmo menino observando, assustado, o olhar raivoso de sua avó, fixo em Tio Mário (cf. SANTIAGO, 1992, p. 11), ainda mais um menino - aquele que narra sua vida em Heranças - registrado "nos instantâneos de pai e filho de mãos dadas a dar um passo a mais pela Avenida Afonso Pena" (SANTIAGO, 2008, p. 50). Também, esse resgate literário de memória encaixa, no cotidiano da criança de pequena cidade do interior, os heróis do cinema e dos quadrinhos, companheiros indispensáveis daquele que ia "[c]rescendo durante a guerra numa província ultramarina" (SANTIAGO, 1978).

Para o leitor, que conviveu imaginariamente com todos esses meninos, a amostra do livro em processo apresenta mais uma experiência artístico-pensante de Santiago. A evocação de imagens da memória surge elaborada através de encadeamentos, cortes, articulação de informações geográficas, econômicas e sociais, de tal modo que a curiosidade, voltada para fora do texto, em bisbilhotice sobre a pessoa do escritor, vai sendo sistematicamente frustrada. $\mathrm{O}$ que se encontra, durante a leitura, são experimentos técnico-estéticos voltados para a recuperação não propriamente dos antecedentes da vida, mas da aquisição dos saberes que foram compondo a escrita literária. $\mathrm{O}$ deslizamento frequente da narrativa biográfica à autobiográfica em Mil rosas roubadas traça uma trajetória de pesquisador e de artista em recolha de todo e qualquer material significativo que tenha composto o quebra-cabeças de sua formação.

Ainda que todas as referências históricas e geográficas da escrita (auto)biográfica sejam verificáveis, não é seu rigor que interessa à dimensão crítica dessa tarefa importante. Em Machado, ensaio críticoficcional, publicado em 2016, Silviano Santiago exibe uma ampla pesquisa sobre o Rio de Janeiro da belle époque para fundamentar a importância da leitura cruel desses dados feita pelos romances Esaú e Jacó e Memorial de Aires. No confronto com a palavra dos conferencistas 
do período e com a arquitetura art nouveau, que reforma a cidade em termos da razão moderna, a literatura machadiana coloca-se em diferença. A construção ficcional enviesa "o eixo de sustentação" (SANTIAGO, 2016, p. 224) dos volumes de sua arquitetura e escapa à retórica que os contemporâneos aplaudem.

Tendo-se apropriado do título de um poema de Murilo Mendes, “O menino sem passado" (MENDES, 1994, p. 88), para publicar a amostra de autobiografia de escritor, Santiago sinaliza em direção ao estatuto poético de sua escrita de feição memorialística. Como o trecho estampado na revista nomeia-se "Sonâmbulo" (SANTIAGO, 2018, p. 45), seus parágrafos dão conta do mundo infantil, onde hábitos familiares ora misturam-se ora contrapõem-se às cenas de filmes de aventura. Assim também a falta da mãe tanto se acentua quanto é atenuada pela proximidade silenciosa com o pai, que lê o jornal e ouve as notícias do rádio. Sensações e afetos exteriorizados compõem a fantasmagoria de entre-sono-e-vigília característica do imaginário do escritor. É nesse lugar virtual que se atravessam as perspectivas do menino e do adulto, do pesquisador e do artista, pondo em questão as certezas do senso comum e as verdades da história. Juntam-se, no escritor, as birras de criança, a rebeldia adolescente e as manias do velho para atestar a irrepresentabilidade dos fatos e manter um discurso sonâmbulo de plena lucidez.

\section{Referências}

MENDES, Murilo. O menino sem passado. In: MENDES, Murilo; PICCHIO, Luciana Stegagno (org.). Poesia completa e prosa. Rio de Janeiro: Nova Aguilar, 1994.

SANTIAGO, Silviano. Crescendo durante a guerra numa província ultramarina. Rio de Janeiro: Francisco Alves, 1978.

SANTIAGO, Silviano. Família. Blog do Instituto Moreira Salles, Rio de Janeiro, 16 maio 2017. Disponível em: https://ims.com.br/por-dentroacervos/familia/. Acesso em: 30 set. 2019.

SANTIAGO, Silviano. Heranças. Rio de Janeiro: Rocco, 2008.

SANTIAGO, Silviano. Machado. São Paulo: Companhia das Letras, 2016. 
SANTIAGO, Silviano. Menino sem passado. Olympio: literatura e arte, Belo Horizonte, n. 1, maio 2018.

SANTIAGO, Silviano. Mil rosas roubadas. São Paulo: Companhia das Letras, 2014.

SANTIAGO, Silviano. O falso mentiroso. Rio de Janeiro: Rocco, 2004.

SANTIAGO, Silviano. Para uma poética da encenação. In: .35 ensaios de Silviano Santiago. Organização de Italo Moriconi. São Paulo: Companhia das Letras, 2019.

SANTIAGO, Silviano. Stella Manhattan. Rio de Janeiro: Nova Fronteira, 1985.

SANTIAGO, Silviano. Uma história de família. Rio de Janeiro: Rocco, 1992. 